\title{
A rare case of short stature - pituitary stalk transection syndrome
}

\author{
Chadalawada L. ${ }^{1}$, Nimmagadda R. ${ }^{2}$, Vupputuri H. ${ }^{3}$, Bhimireddy V. ${ }^{4}$ \\ ${ }^{1}$ Dr. Lakshmipriya Chadalawada, Resident, Department of Paediatrics, NRI Medical College and General Hospital, \\ Chinakakani, Andhra Pradesh, India, ${ }^{2}$ Dr. Rachana Nimmagadda, Resident, Department of Paediatrics, NRI Medical \\ College and General Hospital, Chinakakani, Andhra Pradesh, India, ${ }^{3}$ Dr. Hemanth Vupputuri, Senior PG Registrar, \\ Department of Neurological Sciences, Christian Medical College, Vellore, Tamil Nadu, India, ${ }^{4}$ Dr. Vijayalakshmi \\ Bhimireddy, Professor and Head of the Department, Department of Paediatrics, NRI Medical College and General \\ Hospital, Chinakakani, Andhra Pradesh, India.
}

Corresponding Author: Dr. Lakshmipriya Chadalawada, Resident, Department of Paediatrics, NRI Medical College and General Hospital, Chinakakani, Andhra Pradesh, India, E-mail: priyachadl@gmail.com

\begin{abstract}
Short stature due to Growth hormone deficiency could be due to multiple etiologies. One such rare cause is the Pituitary stalk transection syndrome which is characterized by a triad of thin or absent pituitary stalk, aplasia or hypoplasia of the anterior pituitary and absent or ectopic posterior pituitary seen on magnetic resonance imaging (MRI). The early identification of growth hormone deficiency through growth hormone stimulation tests, evaluation of the hypothalamicpituitary anatomy by performing MRI brain and the early initiation of growth hormone replacement therapy may salvage the child from pathological short stature.
\end{abstract}

Keyword: Pituitary stalk, Hypoplasia or aplasia, Ectopic posterior pituitary

\section{Introduction}

Short stature though not a life-threatening condition has significant associated comorbidities and psychosocial impact. Though there are multiple etiologies to this presentation few causes if detected early can be treated and hence totally prevent or partially correct the condition with growth [1]. Identifying these conditions assumes significance as, if left untreated these will result in a permanent short stature which can never be corrected once the child is past his growth spurt [2]. Thus, timely and correct identification of etiology is of prime importance in this condition.

One of the causes of short stature which if identified early can avoid short stature with appropriate treatment is growth hormone deficiency due to pituitary stalk transection. This condition was first described in 1987 after the widespread use of MRI imaging [3]. European data suggests that the incidence of pituitary stalk transection is nearly $0.5 / 10,00,000$ live births [4]. With nearly 50,000 children born in India every day the disease burden is supposed to be high [5], however there are very few reported cases $[6,7]$.

Manuscript received: $2^{\text {nd }}$ February 2019

Reviewed: $11^{\text {th }}$ February 2019

Author Corrected: $16^{\text {th }}$ February 2019

Accepted for Publication: $21^{\text {st }}$ February 2019
The possible explanation being low level of awareness of the condition that it is untreatable leading to delay in seeking medical attention. Even in those children presenting for evaluation, under-evaluation leads to missing this condition.

Pituitary stalk transection can be broadly divided into absence of pituitary stalk, hypoplasia or aplasia of the anterior pituitary and ectopic posterior pituitary gland [3]. Various hypothesis was put forward to explain the findings of absent or hypoplastic pituitary stalk.

One being a traumatic transection during delivery with attempted reformation of the stalk in later years and other being defective development of both adeno- and neurohypophysis with failure of fusion of the pituitary lobes and incomplete pituitary-hypothalamic axis $[8,9]$.

The risk factors of developing this condition is associated with maternal factors like breech presentation, complicated labor and perinatal factors like trauma during birth, prolonged labor or forceps delivery [10]. These children present with short stature, decreased growth rate, seizures, hypotension, intellectual delay and delayed puberty [11]. 


\section{Case Report}

MRI features of pituitary stalk transection with or without ectopic posterior pituitary was reported by many authors $[12,13]$. The principal treatment for this condition is early identification with imaging and growth hormone therapy $[14,15]$. We report a case of an Indian child with short stature who presented to us in early stage of his growth spurt, we discuss the diagnosis of his condition, treatment with growth hormone supplements and follow up along with review of literature.

\section{Case Report}

Clinical Data: A 5 year 6-month-old male child born out of non-consanguineous marriage, first in birth order brought by mother with chief complaint of not gaining weight and height since 1 year of age and complaint of short stature when compared to peers. No h/o malnutrition or any chronic illness. No significant treatment history. Child is term born, cephalic presentation through caesarian section with a birth weight of $2.75 \mathrm{~kg}$ and had uneventful perinatal history and normal developmental history. Child has a younger brother with normal growth and development. No history of short stature in first/second degree relatives.

\section{Anthropometry}

- Weight $-10 \mathrm{~kg}$; SD: -4.5

- Height - $110 \mathrm{~cm}$; SD: -5.9

- BMI - $14.52\left(25-50^{\text {th }}\right.$ centile $)$

- US : LS - 1.18 (Proportionate)

- $\mathrm{HC}-48 \mathrm{~cm}$ (normal)

- Stretched penile length $-3 \mathrm{~cm}$ (expected $-4 \mathrm{~cm})$

- Mid-parental height $-165 \mathrm{~cm}\left(25-50^{\text {th }}\right.$ centile $)$

- Chronological age - 5 year 6 months

- Height age - 1 year 6 months

- Bone age -2years

- Growth velocity-no previous height records.

On general physical examination child had frontal bossing and micropenis. His systemic examination was normal. Child was diagnosed to have Pathological short stature due to endocrine cause probably Growth hormone deficiency for which he was investigated. Routine haematological workup came out to be normal.

\section{Investigations}

- CBP, CUE, Stool exam, LFT, RFT with serum electrolytes - normal

- Thyroid Profile - Normal [ FT4 - 1.29 ng/dl ,TSH $3.38 \mathrm{uiu} / \mathrm{ml}$ ]

- Serum Cortisol - Normal [ $15.46 \mathrm{ug} / \mathrm{dl}]$

- USG Abdomen - Normal
Growth hormone test: Clonidine stimulation test was done which showed Complete growth hormone deficiency. First sample for $\mathrm{GH}$ was taken at 0 minute and then 100 microgram Clonidine tablets was given orally. Second and third GH samples were taken after 1 hour and 2 hours respectively. Child was monitored for hypotension. Results were $0.178,0.269,0.175 \mathrm{ng} / \mathrm{ml}$ at 0 -minute, one hour and 2 hours respectively which implied Complete growth hormone deficiency. (Normal $>10 \mathrm{ng} / \mathrm{ml})$

\section{MRI Brain: s/o Pituitary Stalk Transection}

- Hypoplastic anterior pituitary gland

- Ectopic posterior pituitary at median eminence

- Thin infundibulum

Management: The child was started on Human recombinant growth hormone @ $0.1 \mathrm{IU} / \mathrm{kg} /$ day which showed increment in height of $2.8 \mathrm{cms}$ over 3 months with a growth velocity of $10 \mathrm{cms} /$ year. We planned to continue growth hormone replacement therapy for a duration of 2 years with close follow-up of growth and any progression of multiple pituitary hormones deficiency.

\section{Discussion}

Growth hormone deficiency is a common endocrinologic cause of shortstature. This hormone deficiency maybe idiopathic or associated with organic causes, such as tumors or surgery. Idiopathic growth hormonedeficiency occurs sporadically and maybe isolated or associated with multiplepituitary hormone deficiencies. Clinical isolated growth hormonedeficiency may progress to multiple pituitary hormone deficiency. Isolated growth hormone deficiencyand multiple pituitary hormone deficiency can be due to the pituitary stalktransection syndrome.

In a study by Van der Linden et al. among 21 patients with isolatedgrowth hormone deficiency evaluatedwith MR imaging, 19 had a thin or truncated pituitary stalk [16].

In another study by Triulzi et al., among 101 patients with congenital idiopathic growth hormone deficiency, 59 had ectopic posterior pituitary of which 30 patients had isolated growth hormone deficiency and the rest had multiple pituityary hormone deficiency [17].

The above two studies were compiled cross-sectional studies with no further followup whereas we did a prospective case study with the child started on therapy and regular followup. 
In our case, the male child presented with complaint of short stature. There is no history of perinatal insult or breech presentation. There is no significant past and family history. The child had a normal development in all domains.

On examination the child had height and weight $<3$ percentile for his age and had frontal bossing and micropenis. On investigation, the child had complete growth hormone deficiency along with delayed bone age. MRI brain is suggestive of hypoplastic anterior pituitary gland, ectopic posterior pituitary at median eminence and a thin pituitary stalk.

On the basis of these findings, the diagnosis of Pituitary stalk transection syndrome was made, and patients were started on hormonal replacement therapy. Growth hormone $(\mathrm{GH})$ replacement therapy forms the cornerstone of management of children with growth hormone deficiency (GHD).

It is a liquid preparation given through Automated pen device at a dose of $0.33 \mathrm{mg} / \mathrm{kg} /$ week or $0.14 \mathrm{IU} / \mathrm{kg} /$ day subcutaneously, once daily administration at bedtime.

\section{Conclusion}

A high degree of suspicion is required for preventable causes of growth failure like growth hormone deficiency due to pituitary stalk transection syndrome. Early identification, strict growth monitoring and therapy at the earliest is of paramount importance in such conditions.

They have an excellent opportunity to reach their normal height if they present before epiphyseal closure. Multiple pituitary hormone deficiency should be looked out for, in all these cases. Close follow-up during pubertal period is necessary.

Funding: Nil, Conflict of interest: None initiated, Perission from IRB: Yes

\section{References}

1. Pedicelli S, Peschiaroli E, Violi E, et al. Controversies in the definition and treatment of idiopathic short stature (ISS). J Clin Res Pediatr Endocrinol. 2009; 1 (3): 105-15. doi: 10.4008/jcrpe. v1i3. 53. Epub 2009 Feb 1.

2. Becker, Kenneth L., ed. (2001). Growth and Development in the Normal Infant and Child, Table 7.1. Principles and Practice of Endocrinology and Metabolism (3 ed.). Philadelphia, Pa.:Lippincott, Williams \& Wilkins. p. 69. ISBN 9780781717502.
3. Fujisawa I, Kikuchi K, Nishimura K, et al. Transection of the pituitary stalk: development of an ectopic posterior lobe assessed with MR imaging. Radiology. 1987 Nov;165(2):487-9. DOI:10.1148/ radiology.165.2.3659371

4. El Chehadeh-Djebbar S, Callier P, Masurel-Paulet A, Bensignor C, Méjean N, Payet $\mathrm{M}$, et al. 17q21.31 microdeletion in a patient with pituitary stalk interruption syndrome. Eur J Med Genet. 2011;54:369-73.

5. National Family Health Survey (NFHS) IV (20152016) . International Institute for Population Sciences, Ministry of Health and Family Welfare, Government of India. 2016.

6. Patkar D, Patankar T, Krishnan A, Prasad S, Shah J, Limdi J. MR imaging in children with ectopic pituitary gland and anterior hypopituitarism. J Postgrad Med 199;45(3):81-83

7. Gutch M, Kumar S, Razi SM, et al. Pituitary stalk interruption syndrome: Case report of three cases with review of literature. J PediatrNeurosci. 2014 May; 9(2): 188-91. doi: 10.4103/1817-1745.139363.

8. Chen S, Léger J, Garel C, et al. Growth hormone deficiency with ectopic neurohypophysis: anatomical variations and relationship between the visibility of the pituitary stalk asserted by magnetic resonance imaging and anterior pituitary function. $\mathrm{J}$ Clin Endocrinol Metab. 1999 Jul;84(7):2408-13.

9. Genovese E, Maghnie M, Beluffi G, et al. Hypothalamic-pituitary vascularization in pituitary stalk transection syndrome: is the pituitary stalk really transected? The role of gadolinium-DTPA with spinecho T1 imaging and turbo-FLASH technique. Pediatr Radiol. 1997 Jan; 27(1) : 48-53.DOI:10.1007 / s00247 0050062

10. Rona RJ, Tanner JM. Aetiology of idiopathic growth hormone deficiency in England and Wales. Arch Dis Child. 1977 Mar;52(3):197-208.

11. Simon D, Hadjiathanasiou C, Garel C, Czernichow $\mathrm{P}$, Léger J. Phenotypic variability in children with growth hormone deficiency associated with posterior pituitary ectopia. Clin Endocrinol (Oxf) 2006;64:41622.

12. Kelly WM, Kucharczyk W, Kucharczyk J, et al. Posterior pituitary ectopia: an MR feature of pituitary dwarfism. AJNR Am J Neuroradiol. 1988 May-Jun;9 (3):453-60. 


\section{Case Report}

13. Kikuchi K, Fujisawa I, Momoi T, Yamanaka C, et al. Hypothalamic-pituitary function in growth hormonedeficient patients with pituitary stalk transection. J Clin Endocrinol Metab. 1988 Oct; 67 (4):817-23. DOI: $10.1210 /$ jcem-67-4-817

14. Bar C, Zadro C, Diene G, et al. Pituitary Stalk Interruption Syndrome from Infancy to Adulthood: Clinical, Hormonal, and Radiological Assessment According to the Initial Presentation. PLoS One. 2015 Nov 12;10 (11) : e0142354. doi: 10.1371/ journal. pone.0142354. eCollection 2015.

15. Tauber M, Chevrel J, Diene G, et al. Long-term evolution of endocrine disorders and effect of $\mathrm{GH}$ therapy in 35 patients with pituitary stalk interruption syndrome. Horm Res. 2005;64(6) : 266-73. Epub 2005 Oct 15. DOI: $10.1159 / 000089425$

16. van der Linden AS, van Es HW. Case 112: pituitary stalk transection syndrome with ectopic posterior pituitary gland. Radiology. 2007 May; 243 (2): 594-7. DOI:10.1148/ radiol.2432040385

17. Triulzi F, Scotti G, di Natale B, et al. Evidence of a congenital midline brain anomaly in pituitary dwarfs: a magnetic resonance imaging study in 101 patients. Pediatrics. 1994 Mar;93(3):409-16.

\section{How to cite this article?}

Chadalawada L., Nimmagadda R., Vupputuri H., Bhimireddy V. A rare case of short stature - pituitary stalk transection syndrome. Int J Pediatr Res. 2019;6(02):87-90. doi:10.17511/ijpr.2019.i02.08 